\title{
Short communication: Forage particle size and fat intake affect rumen passage, the fatty acid profile of milk, and milk fat production in dairy cows consuming dried distillers grains with solubles
}

\author{
H. A. Ramirez Ramirez, ${ }^{* 1}$ K. J. Harvatine, $†$ and P. J. Kononoff ${ }^{* 2}$ \\ *Department of Animal Science, University of Nebraska, Lincoln 68583-0908 \\ †Department of Animal Science, The Pennsylvania State University, University Park 16802
}

\begin{abstract}
Four ruminally cannulated Holstein cows averaging $( \pm \mathrm{SD}) 116 \pm 18 \mathrm{~d}$ in milk and $686 \pm 52 \mathrm{~kg}$ of body weight were used in a $4 \times 4$ Latin square design with a $2 \times 2$ factorial arrangement of treatments to test the effects of forage particle size and concentration of corn oil on milk fat depression. Cows were housed in individual stalls, milked daily at 0700 and $1800 \mathrm{~h}$, and individually fed daily at $0900 \mathrm{~h}$ for ad libitum consumption allowing approximately $10 \%$ orts. Four 28 -d periods, in which each cow was offered 1 of 4 total mixed rations, included reduced-fat dried distillers grains with solubles at $30 \%$ of dietary dry matter and differed in forage particle size by inclusion of chopped grass hay (LONGP) or grass hay pellets (SHORTP) and 0 or $2 \%$ corn oil (CO). Dietary treatments were $0 \%$ corn oil + short particle size (CO0+SHORTP), $0 \%$ corn oil + long particle size $(\mathrm{CO} 0+\mathrm{LONGP}), 2 \%$ corn oil + short particle size (CO2+SHORTP), and $2 \%$ corn oil + long particle size (CO2+LONGP). Dry matter intake and milk yield were not affected by treatment averaging $26.5 \pm 1.19 \mathrm{~kg} / \mathrm{d}$ and $32.8 \pm 3.34 \mathrm{~kg} / \mathrm{d}$, respectively. A decrease was found in $3.5 \%$ fat-corrected milk with the inclusion of oil resulting in 34.6 and $26.6 \pm 2.6 \mathrm{~kg} / \mathrm{d}$ for 0 and $2 \%$ oil diets, respectively. An oil $\times$ size interaction was found for milk fat concentration resulting in $2.27,3.02,3.62$, and $3.62 \pm 0.23 \%$ for CO2+SHORTP, CO2+LONGP, CO0+SHORTP, and CO0+LONGP, respectively. Fat yield was reduced from 1.22 to 0.81 $\pm 0.09 \mathrm{~kg} / \mathrm{d}$ with $2 \%$ oil diets. Cows consuming diets with long particle size spent 29 more minutes eating compared with the cows consuming short particle size (198 and $169 \pm 15 \mathrm{~min} / \mathrm{d}$ ). Rumination time decreased from 504 to $400 \pm 35 \mathrm{~min} / \mathrm{d}$ for cows consuming short
\end{abstract}

\footnotetext{
Received June 24, 2015.

Accepted September 17, 2015.

${ }^{1}$ Current address: Department of Animal Science, Iowa State University, Ames, IA 50011.

${ }^{2}$ Corresponding author: pkononoff2@unl.edu
}

particle size compared with long particle size. Total chewing was reduced from 702 to $570 \pm 4 \mathrm{~min} / \mathrm{d}$ when cows consumed short particle size. Feeding long particle size decreased rate of passage of dry matter from 3.38 to $2.89 \pm 0.42 \% / \mathrm{h}$; concomitantly mean retention time increased from 31.7 to $38.4 \pm 5.36 \mathrm{~h}$ for diets containing long particle size. The results of this experiment show that effects of oil on milk fat depression were less severe when cows consumed long particle size, suggesting that dietary manipulations that modify rumen kinetics also affect milk fat production in dairy cows consuming reduced-fat dried distillers grains with solubles supplemented with corn oil.

Key words: chewing activity, milk fat, rumen kinetics

\section{Short Communication}

Compared with long forage particles, small forage particles pass out of the rumen more rapidly and may result in reduced rumination times and rumen $\mathrm{pH}$. Saliva production is an important feature of the ruminant digestive process because saliva acts as a buffer agent that helps maintain $\mathrm{pH}$ in the rumen. Saliva secretion occurs continuously but is more pronounced during eating and rumination (Maekawa et al., 2002). Rapid fermentation of carbohydrates, lower buffering capacity in the rumen, and high supply of PUFA are factors that contribute to milk fat depression (MFD; Kalscheur et al., 1997a,b). These changes may lead to low ruminal $\mathrm{pH}$ and altered biohydrogenation pathways that result in formation of bio-active isomers of CLA that may inhibit milk fat synthesis in the mammary gland (Bauman and Griinari, 2001).

The corn-ethanol industry currently implements technology that partially removes fat from the solubles fraction of dried distillers grains with solubles (DDGS); this results in production of reduced-fat DDGS (RFDDGS). The removal of fat is considered as removal of energy from DDGS; interestingly, reports by Mjoun et al. (2010) and Castillo-Lopez et al. (2014b) indicate that cows maintain milk yield when RFDDGS are fed up to 
$30 \%$ of dietary DM. This may be because dairy cows may be more energetically efficient when fed RFDDG (Foth et al., 2015). If energy shortage is of concern, fat supplementation may compensate, but according to Abdelqader et al. (2009) and Ramirez Ramirez et al., (2015), supplementation with corn oil may result in MFD associated with high supply of rich source of long-chain PUFA. In addition, rations containing high proportions of DDGS are often low in effective fiber; therefore, we sought to further evaluate the effects of added fat and forage particle size milk fat production and rumen fermentation of dairy cows fed RFDDGS. We hypothesize that the addition of long-chain PUFA to diets containing a high inclusion rate of RFDDGS supplemented with corn oil will result in MFD but that increasing forage particle size may reduce the extent of this condition.

Experimental cows were cared for according to the guidelines stipulated by the University of Nebraska Institutional Animal Care and Use Committee. Cows were housed in individual stalls and milked at 0700 and 1800 $\mathrm{h}$ and had access to an exercise area for approximately $2 \mathrm{~h}$ after each milking session. Cows were individually fed once daily at $0900 \mathrm{~h}$ for ad libitum consumption allowing approximately $10 \%$ refusals; which were collected, weighed, and recorded individually. Four ruminally cannulated Holstein cows averaging $( \pm$ SD) $116 \pm$ $18 \mathrm{DIM}$ and $686 \pm 52 \mathrm{~kg}$ of $\mathrm{BW}$ were used in a $4 \times 4$ Latin square design with a $2 \times 2$ factorial arrangement of treatments to test the effects of forage particle size and concentration of corn oil on milk fat depression. In four 28-d periods, each cow was offered 1 of 4 TMR (Table 1) that included RFDDGS at 30\% (DM basis). Days 1 to 21 of each period were considered as an adaption period; data collected during the last $7 \mathrm{~d}$ were considered for statistical analyses. Dietary treatments were (on a DM basis) $0 \%$ corn oil + short forage particle size (CO0+SHORTP $), 0 \%$ corn oil + long forage particle size (CO0+LONGP), $2 \%$ corn oil + short forage particle size (CO2+SHORTP), and $2 \%$ corn oil + long forage particle size (CO2+LONGP). The RFDDGS was originated from a back-end process of centrifugation of the condensed solubles portion of the feedstuff (POET Nutrition Inc., Sioux Falls, SD). To manipulate forage particle size, a single lot of timothy grass (Phleum pratense) was harvested and processed as hay into round bales or ground through a $4.8-\mathrm{mm}$ screen to make pellets (Dehy Alfalfa Mills, Arlington, NE). Subsequently, round bales of grass hay were chopped in a tub grinder equipped with a $7.62-\mathrm{cm}$ screen at the Agricultural Research and Development Center of the University of Nebraska (near Mead, NE). By design, treatments were similar in chemical composition except for ether extract content when diets included corn oil. When formulating the $2 \%$ corn oil diets, a proportion of soy hulls was removed to allow inclusion of corn oil.

Samples of TMR, forages, and concentrates were collected on d 27 and 28 of each period and subsequently pooled by period. The Penn State Particle Separator was used to measure particle size distribution of the different TMR as described by Heinrichs and Kononoff (2002). Feed samples were dried at $55^{\circ} \mathrm{C}$ in a forced-air oven to determine DM. After determination of DM, samples were ground (1-mm screen; Wiley mill, Arthur H. Thomas Co., Philadelphia, PA) and stored at room temperature. Samples of forages and concentrates were analyzed by an external laboratory (Cumberland Valley Analytical Services, Hagerstown, MD). Analyses included DM (method 930.15; AOAC International, 2000), N (method 990.03; Leco FP-528 Nitrogen Combustion Analyzer, Leco Corp. St. Joseph, MI), NDF (Van Soest et al., 1991), starch (Hall, 2009), ether extract using diethyl ether as the solvent (method 2003.05; AOAC International, 2006), ash (method 942.05; AOAC International, 2000), and $\mathrm{P}$ by inductively coupled plasma (method 985.01; AOAC International, 2000). Chemical composition of TMR was estimated from analysis of forages and concentrates and their proportion in the diet.

Milk production was measured daily and milk samples were collected during the a.m. and p.m. milking of $d$ 26,27 , and 28 and preserved using a pellet of 2-bromo2-nitropropane-1,3 diol. Milk samples were analyzed for fat, true protein (AOAC International, 2000), lactose, and SNF using a B2000 Infrared Analyzer (Bentley Instruments, Chaska, MN) by Heart of America DHIA (Manhattan, KS), and MUN was determined using a modified Berthelot reaction concentration (ChemSpec 150 Analyzer, Bentley Instruments) by the same laboratory. Yields of milk components were estimated according to milk weight and time of collection. Daily milk yield was averaged over the last $7 \mathrm{~d}$ of each period. An additional milk sample was taken at the times previously described for determination of individual fatty acids. For this purpose, individual samples were frozen immediately after milking, and at the completion of the experiment, one composite per cow in each period was obtained by mixing proportional aliquots according to milk weight and time of collection. Fatty acid analysis of milk was performed by an external laboratory (Department of Animal Science, The Pennsylvania State University, University Park) as described by Rico and Harvatine (2013).

On d 21 of each period, ruminal fluid samples were collected over 10 time points $(0,1,2,4,6,8,11,14,18$, and $23 \mathrm{~h}$ ) postfeeding. At each time point, samples of 
Table 1. Ingredient and analyzed chemical composition of experimental diets

\begin{tabular}{|c|c|c|c|c|}
\hline \multirow[b]{3}{*}{ Item } & \multicolumn{4}{|c|}{ Dietary treatment } \\
\hline & \multicolumn{2}{|c|}{$0 \%$ Corn oil } & \multicolumn{2}{|c|}{$2 \%$ Corn oil } \\
\hline & Short $^{1}$ & Long & Short & Long \\
\hline \multicolumn{5}{|c|}{ Diet ingredient, $\%$ of DM } \\
\hline Corn silage & 19.1 & 19.1 & 19.1 & 19.1 \\
\hline Alfalfa hay & 12.1 & 12.1 & 12.1 & 12.1 \\
\hline Timothy hay & - & 18.1 & - & 18.1 \\
\hline Timothy pellets & 18.1 & - & 18.1 & - \\
\hline RFDDGS $^{2}$ & 29.1 & 29.1 & 29.1 & 29.1 \\
\hline Corn oil & - & - & 2.0 & 2.0 \\
\hline Soybean hulls & 8.0 & 8.0 & 6.0 & 6.0 \\
\hline Concentrate $\operatorname{mix}^{3}$ & 13.6 & 13.6 & 13.6 & 13.6 \\
\hline \multicolumn{5}{|l|}{ Chemical, $\%$ of DM } \\
\hline $\mathrm{CP}$ & 18.2 & 18.0 & 18.4 & 18.2 \\
\hline NDF & 34.7 & 35.3 & 34.5 & 35.1 \\
\hline Starch & 17.6 & 17.7 & 16.9 & 17.0 \\
\hline Ether extract & 3.4 & 3.5 & 5.2 & 5.0 \\
\hline $\mathrm{NFC}^{4}$ & 36.8 & 36.4 & 35.2 & 34.8 \\
\hline Ash & 8.8 & 8.9 & 8.6 & 8.7 \\
\hline \multicolumn{5}{|c|}{ Fatty acid, g/100 g of DM } \\
\hline $\mathrm{C} 16: 0$ & 0.62 & 0.61 & 0.87 & 0.80 \\
\hline C18:0 & 0.12 & 0.11 & 0.16 & 0.14 \\
\hline cis-9 C18:1 & 0.87 & 0.83 & 1.45 & 1.27 \\
\hline cis-11 C18:1 & 0.03 & 0.03 & 0.04 & 0.04 \\
\hline C18:2n-6 & 1.77 & 1.70 & 2.80 & 2.46 \\
\hline C18:3n-3 & 0.19 & 0.28 & 0.20 & 0.30 \\
\hline C20:0 & 0.02 & 0.02 & 0.03 & 0.03 \\
\hline Others $^{5}$ & 0.23 & 0.26 & 0.30 & 0.33 \\
\hline Total unsaturated & 2.89 & 2.88 & 4.54 & 4.11 \\
\hline Total saturated & 0.81 & 0.80 & 1.11 & 1.02 \\
\hline Total & 3.85 & 3.86 & 5.85 & 5.37 \\
\hline \multicolumn{5}{|c|}{ Particle size distribution } \\
\hline$>19.0 \mathrm{~mm}$ & 0.3 & 5.4 & 0.4 & 5.1 \\
\hline $19.0-8.0 \mathrm{~mm}^{6}$ & 26.0 & 16.9 & 25.4 & 15.6 \\
\hline $8.0-1.18 \mathrm{~mm}$ & 29.3 & 29.1 & 28.6 & 28.6 \\
\hline$<1.18 \mathrm{~mm}$ & 44.3 & 48.6 & 45.5 & 50.6 \\
\hline
\end{tabular}

${ }^{1}$ Forage particle size short $=$ pelleted grass hay; long = chopped grass hay.

${ }^{2}$ Reduced-fat corn dried distillers grains with solubles.

${ }^{3}$ Formulated to contain $66.7 \%$ ground corn, $14.7 \%$ by-pass protein (Soypass, Lignotech, Rothschild, WI), $6.6 \%$ limestone, $5.1 \%$ sodium bicarbonate, $2.2 \%$ dicalcium phosphate, $1.6 \%$ salt, $1.3 \%$ magnesium oxide, $0.9 \%$ mineral mix (formulated to contain $1.0 \% \mathrm{Ca}, 0.50 \% \mathrm{P}, 0.36 \% \mathrm{Mg}, 1.3 \% \mathrm{~K}$ ), $0.9 \%$ vitamin mix (formulated to supply approximately 120,000 IU/d vitamin A, 24,000 IU/d of vitamin D, and $800 \mathrm{IU} / \mathrm{d}$ vitamin $\mathrm{E}$ in total ration). ${ }^{4} \mathrm{NFC}$ calculated by difference: $100-(\% \mathrm{NDF}+\% \mathrm{CP}+\%$ fat $+\%$ ash $)$.

${ }^{5}$ Includes unknown fatty acids and fatty acids that were present at concentrations $<0.02 \mathrm{~g} / 100 \mathrm{~g}$ of DM (14:0, $14: 1,16: 1,17: 0,18: 3,20: 1,20: 2,22: 0,22: 4,24: 0,24: 1)$.

rumen content were collected from the cranial, caudal, left, and right lateral areas of the rumen and mixed to become a uniform sample per cow. This material was then strained through 4 layers of cheesecloth to obtain rumen fluid, and the $\mathrm{pH}$ was measured immediately. The samples of rumen fluid were immediately frozen and later analyzed individually for ammonia using a colorimetric assay. Evacuation of total rumen contents was performed $2 \mathrm{~h}$ prefeeding on d 27 and $2 \mathrm{~h}$ postfeeding on $\mathrm{d} 28$ of each period to determine rumen kinetics according to Robinson et al. (1987) using the following equation:

$$
\begin{aligned}
& \text { Rate of passage }\left(\mathrm{k}_{\mathrm{p}}\right), \% / \mathrm{h}= \\
& \frac{1}{24} \times \frac{\text { fecal output }(\mathrm{kg} / \mathrm{d})}{\text { rumen pool size }(\mathrm{kg})} \times 100 .
\end{aligned}
$$

During each evacuation, whole rumen contents were weighed and a sample was obtained by compositing approximately $5 \%$ of the mass as the material was being put back in the rumen. Determination of DM and NDF on rumen contents was performed as described previously for TMR analysis for samples collected in each day; values from each day of collection were averaged 
by cow in each period. Fecal output was estimated using indigestible ADF as an internal marker (Huhtanen et al., 1994). Mean retention time was calculated as the reciprocal of $\mathrm{k}_{\mathrm{p}}$.

Measurements of chewing activities were carried out over a 24-h period starting on d 25 immediately after feeding through a visual observation method with 5-min intervals (Kononoff et al., 2002). Classification of behaviors were eating, ruminating, and others (including self-grooming, drinking, resting, idling). The sum of eating plus ruminating was considered as total chewing activity. It was assumed that the incidence of an activity lasted for the entire 5-min interval; thus, the total number of minutes in each activity was estimated as the sum of each observation multiplied by 5 . Aspects of the daily routine of the animals remained unchanged during this observational period.

Production data were analyzed as a $4 \times 4$ Latin square using the MIXED procedure of SAS (version 9.2, SAS Institute Inc., Cary, NC). Treatment and period were considered as fixed effect in the model, whereas cow was considered as a random effect. Data obtained from ruminal fluid were analyzed as repeated measures using the first-order ante dependence covariance structure in SAS (version 9.2, SAS Institute Inc.). The effects of period, treatment, hour, and treatment $\times$ hour interaction were considered as fixed, and cow was considered as a random effect. Because of unequally spaced rumen sampling, the weighted averages for rumen data were determined by calculating the area under the response curve according to the trapezoidal rule (Shipley and Clark, 1972). Statistical significance for all treatments effects was declared at $P \leq 0.05$; trends are discussed at $P \leq 0.15$. All results are presented as least squares means \pm the largest standard error of the mean.

We evaluated the effects of feeding short particles of grass hay with corn oil supplementation on the productive response of dairy cows fed RFDDGS. The particle size distribution of TMR is listed in Table 1. It is important to note that all SHORTP treatments contained pelleted feed and that upon sieving, these pellets were retained on the $8.00-\mathrm{mm}$ sieve. Given that forage for pellets was ground through a $4.8-\mathrm{mm}$ screen, it is likely that most particles contained in the pellets were less than $8.0 \mathrm{~mm}$. Although the true proportions of pellet material that may have been retained in the $8.0-\mathrm{mm}$ sieve remains unknown, it is likely that the SHORTP treatments were finer than reported in Table 1. No interactions were found between forage particle size and oil on milk yield and milk compositional traits (data not shown) except for milk fat concentration $(P=0.03$; Table 2). Increasing the physical size of forage particles may influence DMI through distention of the reticulo- rumen with long particles limiting feed intake related to greater rumen fill (Allen, 1996). Interestingly, DMI did not differ among treatments and averaged $26.5 \pm 1.19$ $\mathrm{kg} / \mathrm{d}$, but increasing the concentration of oil tended $(P$ $=0.11$ ) to decrease DMI by $1.8 \mathrm{~kg} / \mathrm{d}$ compared with low oil. Milk yield was not affected by treatments and averaged $32.8 \pm 3.34 \mathrm{~kg} / \mathrm{d}$. A tendency $(P=0.09)$ was observed to decrease milk yield with high oil diets by $2.3 \mathrm{~kg} / \mathrm{d}$ compared with low oil diets, which may be explained by the tendency to reduce DMI in those particular treatments. A decrease $(P<0.01)$ was observed in $3.5 \%$ FCM with high oil diets compared with low oil, resulting in 26.6 and $34.6 \pm 2.6 \mathrm{~kg} / \mathrm{d}$, respectively. Table 2 presents characteristics of milk fat, chewing activities, and rumen kinetics; the oil $\times$ size interaction $(P=0.03)$ for milk fat concentration resulted in $2.27,3.02,3.62$, and $3.62 \pm 0.23 \%$ for $\mathrm{CO} 2+$ SHORTP, CO2+LONGP, CO0+SHORTP, and CO0+LONGP, respectively. Fat yield was reduced $(P<0.01)$ from 1.22 to $0.81 \pm 0.10 \mathrm{~kg} / \mathrm{d}$ with high oil diets. Also, an interaction was observed between oil and forage particle size $(P<0.01)$ affecting concentration and yield of trans-10,cis-12 CLA. Yield of this fatty acid was $0.35 \pm$ $0.06 \mathrm{~g} / \mathrm{d}$ for cows consuming CO2+SHORTP and 0.11 $\pm 0.06 \mathrm{~g} / \mathrm{d}$ for cows consuming CO2+LONGP. Concentration and yield of this fatty acid were negligible for cows consuming CO0+SHORTP and CO0+LONGP; this observation suggests greater activity of rumen biohydrogenation of PUFA in diets containing long particles. In the mammary gland, the trans-10, cis-12 isomer of CLA is a potent inhibitor of de-novo synthesis and absorption of preformed fatty acids from the bloodstream (Chouinard et al., 1999; Peterson et al., 2003). Accordingly, we observed a remarkable reduction in concentration $(P=0.03)$ and yield of fatty synthesized in the mammary gland with high inclusion of oil and short particles.

Cows consuming diets with long particle size spent 29 more minutes eating $(P=0.02)$ compared with the cows consuming short particle size (198 and 169 $\pm 16 \mathrm{~min} / \mathrm{d})$; increasing oil diets tended $(P=0.10)$ to increase eating time by $17 \mathrm{~min} / \mathrm{d}$ compared with low oil diets. Rumination time decreased $(P<0.01)$ from 503 to $400 \pm 37 \mathrm{~min} / \mathrm{d}$ when cows consumed diets with short particles. Total chewing activity was not affected by concentration of oil, but differences $(P$ $<0.01$ ) were observed between cows consuming long and short particle size, resulting in 701 and $570 \pm 46$ $\mathrm{min} / \mathrm{d}$, respectively. In spite of differences in chewing activity, ruminal $\mathrm{pH}$ was similar $(P=0.17)$ between diets with short and long particles averaging $5.64 \pm$ 0.09. Diets with high oil content resulted in lower $(P$ $=0.05$ ) rumen $\mathrm{pH}$ compared with diets with lower oil 
content, 5.60 and $5.68 \pm 0.09$, respectively; rumen ammonia concentrations were not affected by treatment and averaged $12.9 \pm 2.86 \mathrm{mg} / \mathrm{dL}$.

The concentration of oil and forage particle size did not affect the DM or NDF content of rumen digesta $(P \geq 0.32)$, averaging $15.8 \pm 0.48 \%$ and $62.2 \pm 1.45 \%$, respectively. Rate of passage of DM was affected by concentration of oil $(P=0.02)$ and forage particle size $(P=0.03)$ with no interaction between these factors $(P$ $=0.93)$. Rate of passage was 2.89 and $3.38 \pm 0.42 \% / \mathrm{h}$ for cows consuming long and short forage particle size; for the concentration of oil the rates observed were 2.89 and $3.38 \pm 0.44 \% / \mathrm{h}$ for high and low oil concentration, respectively. Mean retention time of DM increased from 31.6 to $38.4 \pm 5.70 \mathrm{~h}$ for diets containing long forage particle size.
Cows consuming long forage particles spent more time chewing, yet we observed relatively low ruminal $\mathrm{pH}$ across all diets. These observations are in agreement with those by Maekawa et al. (2002) and Yang and Beauchemin (2006) who manipulated forage particle size and feeding regimen, and reported no effects on ruminal $\mathrm{pH}$ despite increased chewing time and saliva production. The lack of effect of increasing chewing time on rumen $\mathrm{pH}$ in our experiment may be the response of several factors. First, it is possible that the fiber from RFDDGS fed in this experiment is readily fermentable. Generally speaking, gas production in the rumen is associated with fermentation and fiber digestion. Accordingly, Kelzer et al. (2010) reported that in vitro gas production of several corn milling co-products is relatively high, suggesting high fermentability of

Table 2. Effects of varying concentration of oil and grass hay particle size in a diet with reduced-fat dried distillers grains with solubles on milk yield and composition, chewing activity, rumen content characteristics, and rumen kinetics

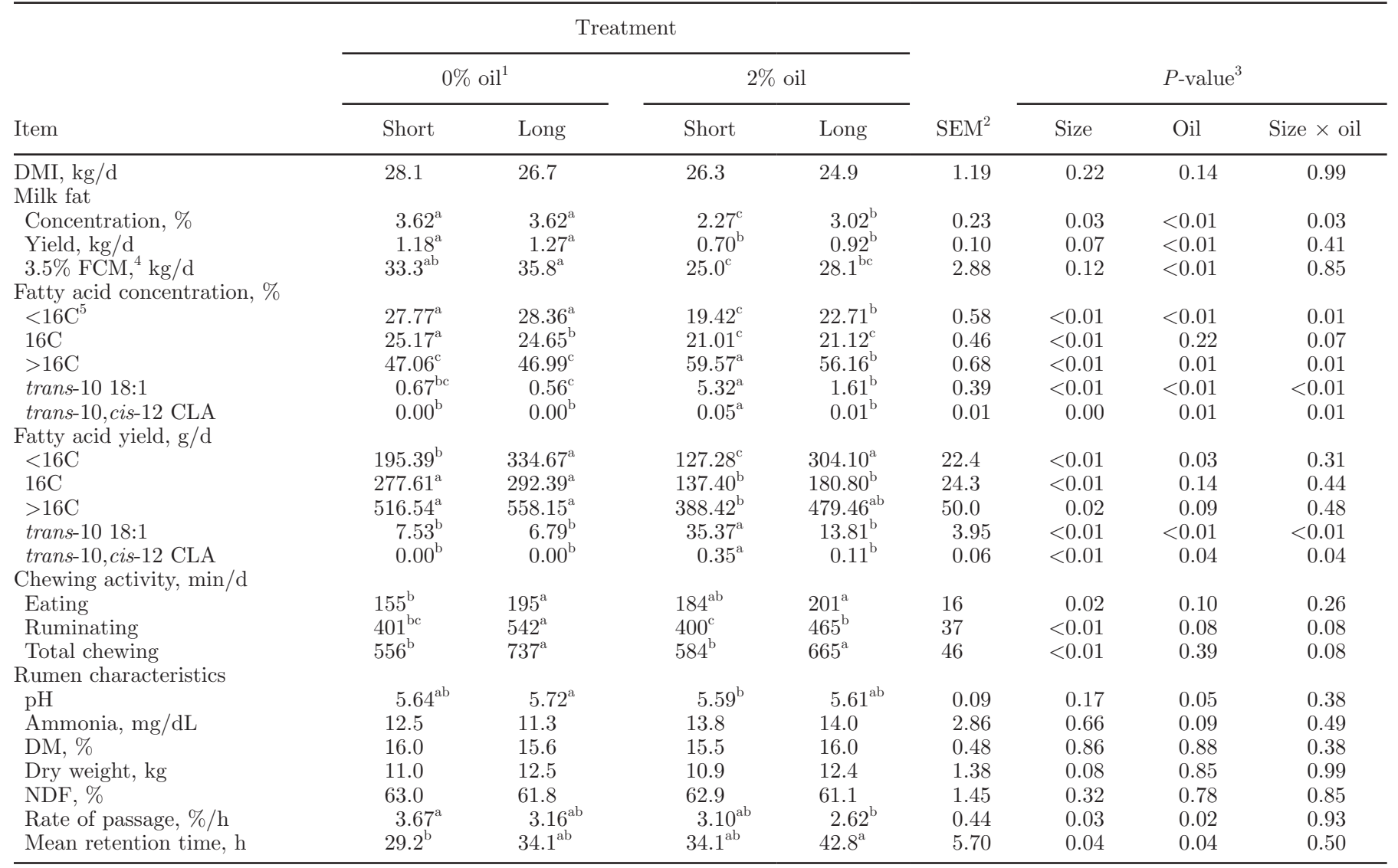

\footnotetext{
${ }^{\mathrm{a}-\mathrm{c}}$ Means in the same row with different superscript differ $(P<0.05)$.

${ }^{1}$ Forage particle size short $=$ pelleted grass hay; long $=$ chopped grass hay.

${ }^{2}$ Highest standard error of treatment mean is shown.

${ }^{3}$ Size $=$ forage particle size; oil $=$ added fat; and size $\times$ oil $=$ interaction between forage particle size and fat.

${ }^{4} 3.5 \% \mathrm{FCM}=[$ milk fat $(\mathrm{kg}) \times 16.218]+[$ milk yield $(\mathrm{kg}) \times 0.4324]$.

${ }^{5}$ Fatty acids less than 16 carbons originate from de novo synthesis, those greater than 16 carbons originate from uptake from plasma, and fatty acids with 16 carbons originate from both sources.
} 
their fiber content. Furthermore, Williams et al. (2010) reported that removing fat from DDGS resulted in faster fermentation. These factors would then increase ruminal digestibility and organic acid production in the rumen. Second, the acidity of the diets may have also influenced ruminal $\mathrm{pH}$ because they were composed principally of corn silage and RFDDGS, both of which are inherently acidic.

We observed that MFD occurred in diets containing added oil and short forage particle size (Table 2). It is noteworthy that the diet which combined oil and short forage particle size resulted in faster rate of passage, lower milk fat concentration and yield, and the highest concentration of trans-10,cis-12 CLA. This fatty acid is known to be a potent inhibitor of milk fat synthesis in the mammary gland. In vitro work by Qiu et al. (2004) reported increased production of CLA isomers at $\mathrm{pH} 5.8$ compared with $\mathrm{pH}$ 6.5. In addition, in vitro work has shown that the extent of biohydrogenation of PUFA is reduced at a faster rate of passage, resulting in an increase of CLA outflow (AbuGhazaleh et al., 2005; AbuGhazaleh and Buckles, 2007). Furthermore, Castillo-Lopez et al. (2014a) reported that animals consuming distillers grains have greater duodenal flow of unsaturated fatty acids. Therefore, it is possible that feeding long forage particles partly alleviated milk fat depression by decreasing rate of passage and increasing retention time in the rumen. This in turn may have allowed for more complete biohydrogenation processes, hence lower yield of trans-10,cis-12 CLA in milk. Further in vivo research is needed to evaluate the effects of rate of passage on extent of biohydrogenation, formation of CLA isomers, and their relationship to milk fat synthesis and production.

\section{ACKNOWLEDGMENTS}

We thank the Nebraska Corn Board (Lincoln, NE) for financial support, POET LLC (Sioux Falls, SD) for providing distillers grains, and the staff of the University of Nebraska dairy research farm for animal care and assistance during the experiment.

\section{REFERENCES}

Abdelqader, M. M., A. R. Hippen, K. F. Kalscheur, D. J. Schingoethe, and A. D. Garcia. 2009. Isolipidic additions of fat from corn germ, corn distillers grains, or corn oil in dairy cow diets. J. Dairy Sci. 92:5523-5533.

AbuGhazaleh, A. A., and W. R. Buckles. 2007. The effect of solids dilution rate and oil source on trans C18:1 and conjugated linoleic acid production by ruminal microbes in continuous culture. J. Dairy Sci. 90:963-969.

AbuGhazaleh, A. A., M. B. Riley, E. E. Thies, and T. C. Jenkins. 2005. Dilution rate and $\mathrm{pH}$ effects on the conversion of oleic acid to trans $\mathrm{C} 18: 1$ positional isomers in continuous culture. J. Dairy Sci. 88:4334-4341.

Allen, M. S. 1996. Physical constraints on voluntary intake of forages by ruminants. J. Anim. Sci. 74:3063-3075.

AOAC International. 2000. Official Methods of Analysis. Vol. 1 and 2. 17th ed. AOAC International, Gaithersburg, MD.

AOAC International. 2006. Official Methods of Analysis. 18th ed. AOAC International, Arlington, VA.

Bauman, D. E., and J. M. Griinari. 2001. Regulation and nutritional manipulation of milk fat: Low-fat milk syndrome. Livest. Prod. Sci. 70:15-29.

Castillo-Lopez, E., H. A. Ramirez Ramirez, T. J. Klopfenstein, C. L. Anderson, N. D. Aluthge, S. C. Fernando, T. Jenkins, and P. J. Kononoff. 2014a. Effect of feeding dried distillers grains with solubles on ruminal biohydrogenation, intestinal fatty acid profile, and gut microbial diversity evaluated through DNA pyro-sequencing. J. Anim. Sci. 92:733-743.

Castillo-Lopez, E., H. A. Ramirez Ramirez, T. J. Klopfenstein, D. Hostetler, K. Karges, S. C. Fernando, and P. J. Kononoff. 2014b. Ration formulations containing reduced-fat dried distillers grains with solubles and their effect on lactation performance, rumen fermentation, and intestinal flow of microbial nitrogen in Holstein cows. J. Dairy Sci. 97:1578-1593.

Chouinard, P. Y., L. Corneau, D. M. Barbano, L. E. Metzger, and D. E. Bauman. 1999. Conjugated linoleic acids alter milk fatty acid composition and inhibit milk fat secretion in dairy cows. J. Nutr. 129:1579-1584.

Foth, A. J., T. Brown-Brandl, K. J. Hanford, P. S. Miller, G. Garcia Gomez, and P. J. Kononoff. 2015. Energy content of reduced-fat dried distillers grains with solubles for lactating dairy cows. J. Dairy Sci. http://dx.doi.org/10.3168/jds.2014-9226.

Hall, M. B. 2009. Analysis of starch, including maltooligosaccharides, in animal feeds: A comparison of methods and a recommended method for AOAC collaborative study. J. AOAC Int. 92:42-49.

Heinrichs, A. J., and P. J. Kononoff. 2002. Evaluating particle size of forages and TMRs using the new Penn State forage particle separator. DAS 02-42. Technical Bulletin of the Pennsylvania State University, College of Agricultural Sciences. Cooperative Extension.

Huhtanen, P., K. Kaustell, and S. Jaakkola. 1994. The use of internal markers to predict total digestibility and duodenal flow of nutrients in cattle given six different diets. Anim. Feed Sci. Technol. 48:211-227.

Kalscheur, K. F., B. B. Teter, L. S. Piperova, and R. A. Erdman. 1997a. Effect of dietary forage concentration and buffer addition on duodenal flow of trans- $\mathrm{C}_{18: 1}$ fatty acids and milk fat production in dairy cows. J. Dairy Sci. 80:2104-2114.

Kalscheur, K. F., B. B. Teter, L. S. Piperova, and R. A. Erdman. 1997b. Effect of fat source on duodenal flow of trans- $\mathrm{C}_{18: 1}$ fatty acids and milk fat production in dairy cows. J. Dairy Sci. 80:21152126.

Kelzer, J. M., P. J. Kononoff, L. O. Tedeschi, T. C. Jenkins, K. Karges, and M. L. Gibson. 2010. Evaluation of protein fractionation and ruminal and intestinal digestibility of corn milling co-products. J. Dairy Sci. 93:2803-2815.

Kononoff, P. J., H. A. Lehman, and A. J. Heinrichs. 2002. A comparison of methods used to measure eating and ruminating activity in cattle. J. Dairy Sci. 85:1801-1803.

Maekawa, M., K. A. Beauchemin, and D. A. Christensen. 2002. Effect of concentrate level and feeding management on chewing activities, saliva production, and ruminal $\mathrm{pH}$ of lactating dairy cows. J. Dairy Sci. 85:1165-1175.

Mjoun, K., K. F. Kalscheur, A. R. Hippen, D. J. Schingoethe, and D. E. Little. 2010. Lactation performance and amino acid utilization of cows fed increasing amounts of reduced-fat dried distillers grains with solubles. J. Dairy Sci. 93:288-303.

Peterson, D. G., E. A. Matitashvili, and D. E. Bauman. 2003. Diet-induced milk fat depression in dairy cows results in increased trans-10, cis-12 CLA in milk fat and coordinate suppression of mRNA abundance for mammary enzymes involved in milk fat synthesis. J. Nutr. 133:3098-3102. 
Qiu, X., M. L. Eastridge, K. E. Griswold, and J. L. Firkins. 2004 Effects of substrate, passage rate, and $\mathrm{pH}$ in continuous culture on flows of conjugated linoleic acid and trans C18:1. J. Dairy Sci. 87:3473-3479.

Ramirez Ramirez, H. A., E. Castillo Lopez, K. J. Harvatine, and P. J. Kononoff. 2015. Fat and starch as additive risk factors for milk fat depression in dairy diets containing corn dried distillers grains with solubles. J. Dairy Sci. 98:1903-1914.

Rico, D. E., and K. J. Harvatine. 2013. Induction and recovery from milk fat depression occurs progressively in dairy cows swithced between diets that differ in fiber and oil concentration. J. Dairy Sci. 96:6621-6630.

Robinson, P. J., S. Tamminga, and A. M. van Vuuren. 1987. Influence of declining level of feed intake and varying proportion of starch in the concentrate on rumen ingesta quantity, composition and kinetics of ingesta turnover in dairy cows. Livest. Prod. Sci. 17:37-62.

Shipley, R. A., and R. E. Clark. 1972. Tracer Methods for In Vivo Kinetics. Academic Press, New York, NY.

Van Soest, P. J., J. B. Robertson, and B. A. Lewis. 1991. Methods for dietary fiber, neutral detergent fiber, and nonstarch polysaccharides in relation to animal nutrition. J. Dairy Sci. 74:3583-3597.

Williams, W. L., L. O. Tedeschi, P. J. Kononoff, T. R. Callaway, S. E. Dowd, K. Karges, and M. L. Gibson. 2010. Evaluation of in vitro gas production and rumen bacterial populations fermenting corn milling (co)products. J. Dairy Sci. 93:4735-4743.

Yang, W. Z., and K. A. Beauchemin. 2006. Effects of physically effective fiber on chewing activity and ruminal $\mathrm{pH}$ of dairy cows fed diets based on barley silage. J. Dairy Sci. 89:217-228. 